\section{International Scientific Journal Theoretical \& Applied Science}

\author{
p-ISSN: 2308-4944 (print) e-ISSN: 2409-0085 (online) \\ Year: 2016 Issue: 3 Volume: 35 \\ Published: $30.03 .2016 \quad$ http://T-Science.org
}

\author{
Amelia Girly L. Aranas \\ BPA., MPA., DPA., Ph.D. \\ College of Arts and Sciences, Main Campu, \\ Cebu Technological University \\ Cebu City, Philippines \\ dr.glaranas@yahoo.com \\ (0939-848-1122)
}

SECTION 19. Management. Marketing. Public administration.

\title{
DECENTRALIZATION OF GOVERNANCE: A SYNTHESIS OF EMPIRICAL EVIDENCE
}

\begin{abstract}
Decentralization whereby local governments are empowered to make all policy and program decisions on behalf of their resident-voters represents a complex system of political, administrative and fiscal autonomy and associated accountability mechanisms to ensure responsiveness and accountability to voters. The purpose of this study is to determine the social conditions, benefits and privileges and the extent of performance along the legislative agenda undertaken in the area of: revenue raising, environmental protection, minimum basic needs, disadvantaged sector, peace and order, agriculture and fisheries and Livelihood program by the Sangguniang Kabataan (SK) members of the 14 barangay, in the municipality of Anahawan, province of Southern Leyte. This research utilized descriptive survey method. The findings reveal that the performance of the SK was very good as per assessed by the barangay elected officials and the identified representative of the locality.

Key words: Social-conditions, Performance, Sangguniang Kabataan, Legislative agenda.

Language: English

Citation: Aranas AGL (2016) DECENTRALIZATION OF GOVERNANCE: A SYNTHESIS OF EMPIRICAL EVIDENCE. ISJ Theoretical \& Applied Science, 03 (35): 1-6.

Soi: http://s-o-i.org/1.1/TAS-03-35-1 Doi: crossef http://dx.doi.org/10.15863/TAS.2016.03.35.1
\end{abstract}

\section{INTRODUCTION}

"Decentralization" generally means the devolution of decision-making powers. A related concept is "deconcentration," in which operations are decentralized, but decision-making powers are not devolved. In addition, decentralization does not necessarily denote erosion neither of central control nor of powers over issues and processes with national dimensions. Decentralized government institutions are doing more of the work of government than ever before. Recent research has responded to this development and deepened our understanding of decentralization and its links to outcomes such as growth, inequality, and political stability, [1].

Empowering the Philippine local government proves important on many fronts. Being the closest agency of the government to the people, it stands critical in identifying what its constituents need and consequently formulating and implementing policies that would best cater to the people. Furthermore, its proximity allows it the advantage of flexibility and efficiency in service-delivery and program implementation that, if properly developed, would significantly advance our country as a nation composed of well-performing units. The 1991 Local Government Code is the single most significant political reform since the restoration of democracy [2]. The sheer difficulty of the Code getting passed by a congress dominated by the same economic and political elites that have ruled the country ever since demonstrates its importance in changing the face of Philippine politics. From its long gestation during the revolutionary government of Aquino to its implementation during the Ramos administration, it has effectively rearranged the distribution of political power in the country.

Decentralization and autonomy are key ingredients to development. Decentralized institutions have at least four (4) advantages that replace Hierarchy with Participation and Teamwork [3], namely: One, decentralized institutions are more flexible than centralized institutions. They can respond quickly to changing circumstances and customers' (constituents') needs. Two, decentralized institutions are more effective than centralized institutions. Frontline organizations, for example local governments, know the local situation better than the national or central government. This significant circumstance suggests that they are more capable at communicating to the locals what needs to 
be done. Three, decentralized institutions are far more innovative than centralized institutions. Knowing the situation, the stakeholders and thus the opportunities and constraints allow local leaders to determine the best means at accomplishing key tasks. Four, decentralized institutions generate higher morale, more commitment, and greater productivity. The ones involved in local governance are themselves stakeholders and are affected by the way the local government works. The commitment comes from the sense of being one with the community, thus the focus and intent to accomplish more.

Good governance may be considered as a guidance or control for an activity to meet a specified objective. Good governance involves legislation and regulatory processes that set standards, monitor and correct defined areas of activity [4].

In 2003, the Government Procurement Reform Act (GPRA) was enacted precisely to ensure that the government, national and local could be made more accountable. The objectives are: transparency, efficiency, and effectiveness [5].

Local governments are at the forefront of governance [6]. Local governments are political subdivisions of a nation-state according to the United Nations. The nature of governance at the local level require substantial flexibility if LGUs are to be effective. The national government may provide a general policy on say transportation and even investment and trade, but the unique conditions on the ground require LGUs to also come up with unique ways of responding to them.

The locale of this research study is the Municipality of Anahawan, province of Southern Leyte it is situated along the seacoast. The mentioned municipality has 14 barangays and the socioeconomic condition of these Sangguniang Kabataan members in the different barangays and their performance will be the concern of this research study and its findings will be made as basis for a barangay action program.

\section{MATERIALS AND METHODS}

This study utilized a descriptive survey design. The researcher employed a non-probability purposive sampling in the selection of the respondents. To determine the benefits and privileges receive and enjoy by the Sangguniang Kabataan members in the fourteen barangays of the Municipality of Anahawan, province of Southern Leyte.

\section{RESULTS AND DISCUSSIONS}

Based on the data gathered, this research study reveals the following findings:

Age Profile of the Sangguniang Kabataan Members

Age Profile of the Sangguniang Kabataan Members

Table 1 $\mathrm{N}=112$

\begin{tabular}{|c|c|c|c|}
\hline Barangay & Age & Frequency & Percentage \\
\hline Cogon & $\begin{array}{l}17-18 \\
19-20 \\
21-u p \\
\end{array}$ & $\begin{array}{l}1 \\
5 \\
2 \\
\end{array}$ & $\begin{array}{l}12.50 \\
62.50 \\
25.00 \\
\end{array}$ \\
\hline Amagusan & $\begin{array}{l}\text { 19-20 } \\
21-\text { up }\end{array}$ & $\begin{array}{l}2 \\
6\end{array}$ & $\begin{array}{l}25.50 \\
74.50\end{array}$ \\
\hline Canlabian & $\begin{array}{l}\text { 19-20 } \\
21-\text { up }\end{array}$ & $\begin{array}{l}1 \\
7\end{array}$ & $\begin{array}{l}12.50 \\
87.50\end{array}$ \\
\hline Calintaan & $\begin{array}{l}17-18 \\
19-20 \\
21-u p\end{array}$ & $\begin{array}{l}3 \\
4 \\
1\end{array}$ & $\begin{array}{l}37.50 \\
50.50 \\
12.50\end{array}$ \\
\hline San Vicente & $\begin{array}{l}17-18 \\
19-20 \\
21-\text { up }\end{array}$ & $\begin{array}{l}1 \\
5 \\
2\end{array}$ & $\begin{array}{l}12.50 \\
62.50 \\
25.00\end{array}$ \\
\hline Poblacion & $\begin{array}{l}17-18 \\
19-20 \\
21-u p\end{array}$ & $\begin{array}{l}1 \\
4 \\
3 \\
\end{array}$ & $\begin{array}{l}12.50 \\
50.00 \\
37.50 \\
\end{array}$ \\
\hline Tagup-on & $\begin{array}{l}17-18 \\
19-20 \\
21-u p\end{array}$ & $\begin{array}{l}2 \\
4 \\
2 \\
\end{array}$ & $\begin{array}{l}25.00 \\
50.00 \\
25.00\end{array}$ \\
\hline Lo-ok & $\begin{array}{l}17-18 \\
19-20 \\
21-\text { up }\end{array}$ & $\begin{array}{l}2 \\
3 \\
3\end{array}$ & $\begin{array}{l}25.00 \\
37.50 \\
37.50\end{array}$ \\
\hline
\end{tabular}




\begin{tabular}{l|lr|ll|ll} 
& ISRA (India) & $=\mathbf{1 . 3 4 4}$ & SIS (USA) & $=\mathbf{0 . 9 1 2}$ & ICV (Poland) & $=\mathbf{6 . 6 3 0}$ \\
Impact Factor: & ISI (Dubai, UAE) $=\mathbf{0 . 8 2 9}$ & PUHL (Russia) $=\mathbf{0 . 1 7 9}$ & PIF (India) & $=\mathbf{1 . 9 4 0}$ \\
& GIF (Australia) & $\mathbf{0 . 5 6 4}$ & ESJI (KZ) & $=\mathbf{1 . 0 4 2}$ & IBI (India) & $\mathbf{4 . 2 6 0}$ \\
& JIF & $\mathbf{1 . 5 0 0}$ & SJIIF (Morocco) & $=\mathbf{2 . 0 3 1}$ & & \\
\hline
\end{tabular}

\begin{tabular}{|l|c|c|c|}
\hline Lewing & $17-18$ & 1 & 12.50 \\
& $19-20$ & 3 & 37.50 \\
& $21-u p$ & 4 & 50.00 \\
\hline Mahalo & $19-20$ & 2 & 25.00 \\
& $21-u p$ & 6 & 74.50 \\
\hline Mainit & $19-20$ & 3 & 37.50 \\
& $21-u p$ & 5 & 50.50 \\
\hline Capacuhan & $19-20$ & 4 & 50.00 \\
& $21-u p$ & 4 & 12.50 \\
\hline Kagingkingan & $17-18$ & 1 & 25.50 \\
& $19-20$ & 2 & 62.00 \\
\hline Manginawong & $21-u p$ & 5 & 25.00 \\
& $19-20$ & 2 & \\
\hline \multicolumn{1}{|c|}{ Total } & $21-u p$ & 6 & \\
\hline
\end{tabular}

Table 1. Age profile. In the barangays of Cogon, Canlabian, San Vicente, Poblacion and Tagup-on, the SK members belong to the bracket of between 21 and above. Also in Lo-ok, Lewing, Mainit, and Capucuhan, Kagingkingan and Maningawong generally most of the SK members were within the age bracket between 19 to 20 years old.

Sex Profile of the Sangguniang Kabataan Members.

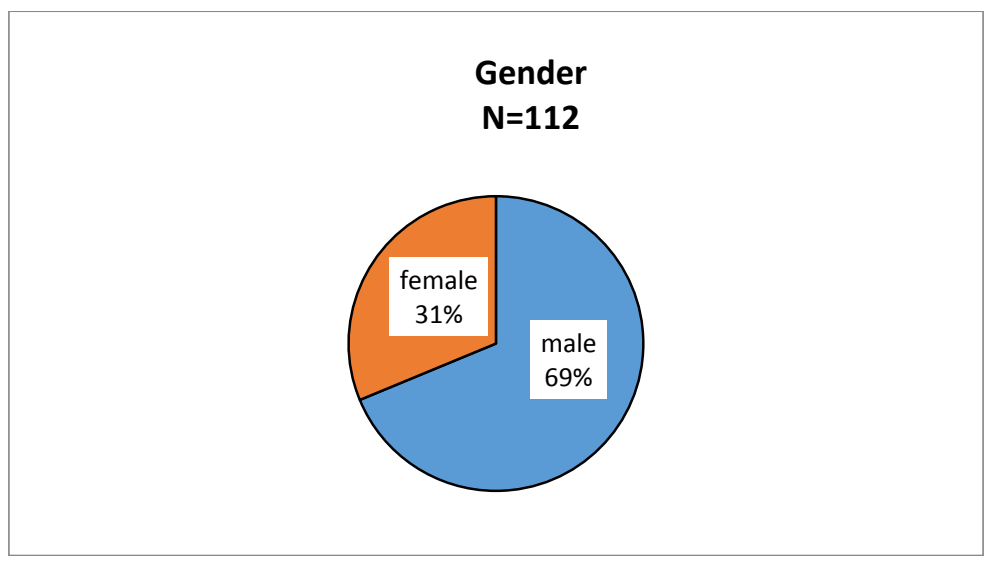

Figure 1 - Sex Profile of the Sangguniang Kabataan Members

$\mathbf{N}=112$

Figure 1. Sex profile. In the barangays of Cogon, Amagusan, Canlabian, Calintaan, San Vicente, Poblacion, Tagup-on, Lewing, Mahalo, Mainit, Capucuhan, Kagingkingan and Manigawong, generally most of the SK members were males. Only in the barangay of Lo-ok were there were females.

\section{Educational Qualifications.}




\begin{tabular}{l|lrl|l|ll} 
& ISRA (India) & $=\mathbf{1 . 3 4 4}$ & SIS (USA) & $=\mathbf{0 . 9 1 2}$ & ICV (Poland) & $=\mathbf{6 . 6 3 0}$ \\
Impact Factor: & ISI (Dubai, UAE) $=\mathbf{0 . 8 2 9}$ & PUHЦ (Russia) & $=\mathbf{0 . 1 7 9}$ & PIF (India) & $=\mathbf{1 . 9 4 0}$ \\
& GIF (Australia) & $\mathbf{0 . 5 6 4}$ & ESJI (KZ) & $=\mathbf{1 . 0 4 2}$ & IBI (India) & $=\mathbf{4 . 2 6 0}$ \\
& JIF & $\mathbf{1 . 5 0 0}$ & SJIF (Morocco) & $\mathbf{2 . 0 3 1}$ & & \\
\hline
\end{tabular}

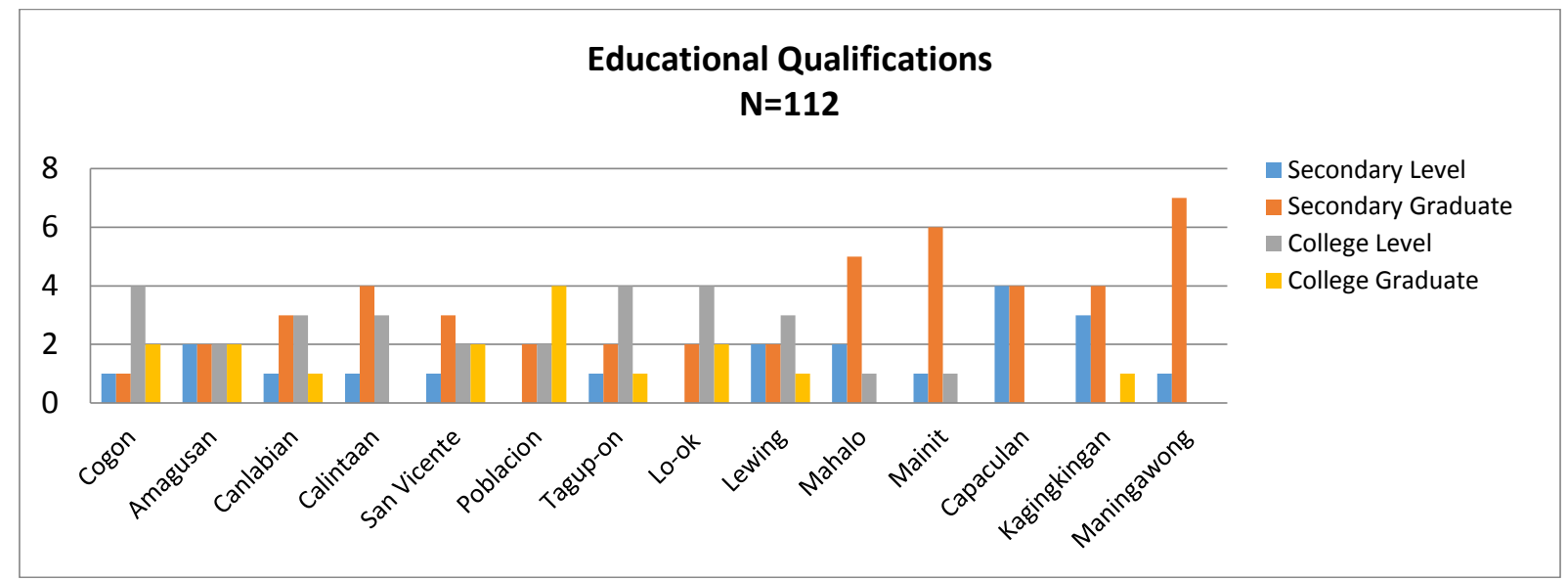

Figure 2 - Educational Qualifications

$\mathrm{N}=112$

Figure 2. Educational Qualifications Profile of the Sangguniang Kabataan members. In the barangays of Cogon, Amagusan, Canlabian, Poblacion, Tagop-on, Lo-ok and Lewing, generally SK members were college level. While in Calintaan, San Vicente, Mahalo, Mainit, Capacuhan,
Kagingking, and Manigawang, generally the SK members in these barangays were secondary graduates.

\section{Training Programs Attended.}

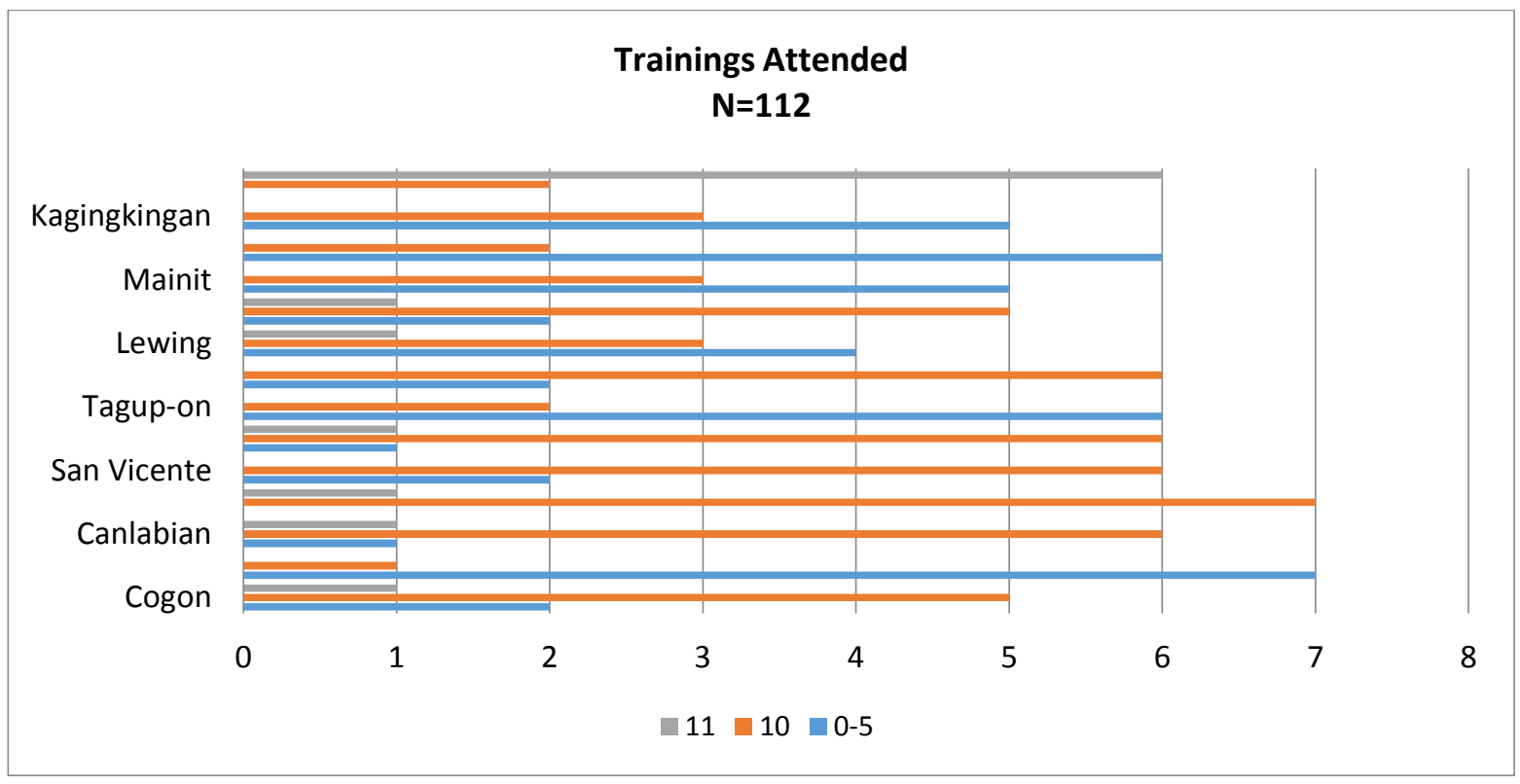

Figure 3 - Training Programs Attended

$\mathrm{N}=112$

Figure 3. Training programs attended. In barangay Cogon, Canlabian, Calintaan, San Vicente, Poblacion, Lo-ok, Lewing and Mahalo, generally the SK members attended between 6 to 10 training programs. While in barangays Amagusan, Tagup-on, Mainit, Capacuhan, Kagingkingan and
Maningawong most SK members attended between 1 to 5 training programs attended. Development goal of the LGU is defined in terms of improved performance in social/human development [10].

\section{Experience as SK members}




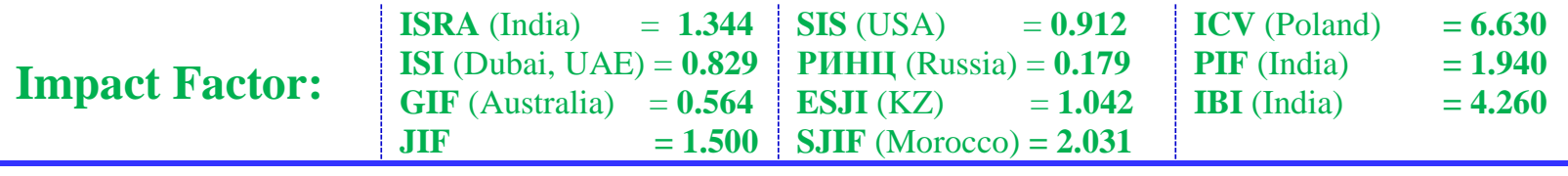

Experience as SK members

Table 2

\begin{tabular}{|c|c|c|c|}
\hline Barangays & $\begin{array}{c}\text { No. of Years Experience as } \\
\text { SK }\end{array}$ & Frequency & Percentage \\
\hline Cogon & $3-5$ years & 8 & 100.00 \\
\hline Amagusan & $\begin{array}{l}1-3 \text { years } \\
3-5 \text { years }\end{array}$ & $\begin{array}{l}2 \\
6\end{array}$ & $\begin{array}{l}25.00 \\
75.00\end{array}$ \\
\hline Canlabian & $3-5$ years & 8 & 100.00 \\
\hline Calintaan & $3-5$ years & 8 & 100.00 \\
\hline San Vicente & $\begin{array}{l}1-3 \text { years } \\
3-5 \text { years }\end{array}$ & $\begin{array}{l}1 \\
7\end{array}$ & $\begin{array}{l}12.50 \\
87.50\end{array}$ \\
\hline Poblacion & $\begin{array}{l}3-5 \text { years } \\
\text { More than } 5 \text { years }\end{array}$ & $\begin{array}{l}7 \\
1\end{array}$ & $\begin{array}{l}87.50 \\
12.50\end{array}$ \\
\hline Tagup-on & $\begin{array}{l}1-3 \text { years } \\
3-5 \text { years }\end{array}$ & $\begin{array}{l}1 \\
7\end{array}$ & $\begin{array}{l}12.50 \\
87.50\end{array}$ \\
\hline Lo-ok & $3-5$ years & 8 & 100.00 \\
\hline Lewing & $3-5$ years & 8 & 100.00 \\
\hline Mahalo & $\begin{array}{l}1-3 \text { years } \\
3-5 \text { years }\end{array}$ & $\begin{array}{l}2 \\
6\end{array}$ & $\begin{array}{l}25.00 \\
75.00\end{array}$ \\
\hline Mainit & $3-5$ years & 8 & 100.00 \\
\hline Capaculan & $\begin{array}{l}3-5 \text { years } \\
\text { More than } 5 \text { years }\end{array}$ & $\begin{array}{l}7 \\
1\end{array}$ & $\begin{array}{l}87.50 \\
12.50\end{array}$ \\
\hline Kagingkingan & $3-5$ years & 8 & 100.00 \\
\hline Maningawong & $3-5$ years & 8 & 100.00 \\
\hline & Total & 112 & \\
\hline
\end{tabular}

Table 2. Experience as SK members. Generally all the SK members in the fourteen barangays of Anahawan, Southern Leyte had experience between 3 to 5 years as SK members. An increase in the output-input ratio of experience does not indicate an improvement in efficiency if the quality of service is not maintained, at the very least. Thus, it is necessary to examine both efficiency and effectiveness measures to see the whole picture of government performance [7].

\section{Benefits and Privileges}

Table 3

\section{Benefits and Privileges}

\begin{tabular}{|l|c|}
\hline \multicolumn{1}{|c|}{ Benefits and Privileges } & Frequency \\
\hline Honoraria & 110 \\
\hline Christmas Bonus & 108 \\
\hline Insurance R.A 6942 & 101 \\
\hline Free Medical Care & 102 \\
\hline $\begin{array}{l}\text { Free Tuition and Free Matriculation School Colleges or } \\
\text { Universities }\end{array}$ & 98 \\
\hline $\begin{array}{l}\text { Entitled to Appropriate Civil } \\
\text { Service Eligibility }\end{array}$ & 96 \\
\hline Leave Privilege & 103 \\
\hline
\end{tabular}

Table 3. Benefits and Privileges of SK members. Generally all the SK members in the fourteen barangays of Anahawan, Southern Leyte have the following benefits and privileges received: honoraria, Christmas bonus, insurance, free medical care, free tuition and matriculation fee in state colleges and universities, after the term of office may receive appropriate Civil Service eligibility and leave privileges being SK members. At the personnel level, Clear career paths and adequate compensation are essential in improving staff productivity. This indicates the need to establish mechanisms to evaluate performance based on achievement [8].

\section{Legislative Agenda.}


Legislative Agenda

\begin{tabular}{|cl|c|c|}
\hline & Legislative Agenda & Mean & Verbal Description \\
\hline 1. & Revenue Rising & 3.62 & Very Good \\
\hline 2. & Environmental Protection & 3.60 & Very Good \\
\hline 3. & Minimum Basis Needs & 3.56 & Very Good \\
\hline 4. & Disadvantaged Sector & 3.61 & Very Good \\
\hline 5. & Agriculture and Fisheries & 3.55 & Very Good \\
\hline 6. & Livelihood Program & 3.77 & Very Good \\
\hline & Mean Average & $\mathbf{3 . 6 2}$ & Very Good \\
\hline
\end{tabular}

Table 4. Extent of performance of the SK members along the legislative agenda undertaken in the areas of: revenue raising; environmental protection; minimum basic needs; disadvantaged sector; agriculture and fisheries and livelihood program have the average weighted men of 3.62 it means Very Good in the implementation of legislative agenda in their respective barangay as per assessed by the clientele. A results-oriented local government gives more attention to funding, monitoring and measuring project/program outcomes rather than inputs [9].

\section{CONCLUSIONS}

The autonomy of the local government unit in determining the social conditions, benefits and privileges and the extent of performance along the legislative agenda reveal that the performance of the Sangguniang Kabataan was very good as per assessed by the barangay elected officials and the identified representative of the locality.

\section{References:}

1. Schneider, Aaron (2003) "Who Gets What from Whom? The Impact of Decentralization on Tax Capacity and Pro-Poor Spending." IDS Working Paper 179, Brighton: IDS.

2. Ringuet, Daniel Joseph, Elsa Estrada (2003) Understanding the Philippines' Economy and Politics since the Return of Democracy in 1986. Contemporary Southeast Asia, Vol. 25, No.2.

3. Osborne David, Ted Gaebler (1992) Reinventing Government: How the Entrepreneurial Spirit is Transforming the Public Sector. New York: Plume.

4. LOGODEF (2006) Revisiting Decentralization in the Philippines.

5. Preschle (2005) Philippine Local Governance in Perspective: Emerging Challenges and Options for Strategic Policy Directions. LOGODEF Journal on Local Governance, Vol. 1, No. 1.

6. Tayao, Edmund Preschle, Klaus (2008) Philippine Local Governance in Perspective: Emerging Challenges and Options for Strategic Policy Directions. LOGODEF Journal on Local Governance, Vol. 1, No. 1.
7. Hatry HP, et.al. (1992) Measuring Local Government Efficiency: A Preliminary Examination. In How Effective Are Your Community Services: Procedures for Measuring their Quality. The Urban Institute.

8. Root HL (1995) Managing Development Through Institution Building. Occasional Papers No. 12. Pasig City, Philippines: Economics and Development Resource Center, Asian Development Bank.

9. Osborne D, Gaeblet T (1992) Reinventing Government. How the Entrepreneurial Spirit is Transforming the Public Sector. New York: Addison-Wesley Publishing Co., Inc

10. Gaffud R (1997) A Concept Paper for the Formulation of Performance Indicators to Monitor and Evaluate the Pursuit of 'Sustained Local Autonomy. Prepared for the NEDA-DAP Project on the Formulation of Performance Indicators and Standards for Development Administration. 